\title{
Hemicellulase production by Aspergillus niger DSM 26641 in hydrothermal palm oil empty fruit bunch hydrolysate and transcriptome analysis
}

\author{
Christoph Ottenheim ${ }^{\mathrm{a}, \mathrm{b}}$, Carl Verdejo ${ }^{\mathrm{b}}$, Wolfgang Zimmermann ${ }^{\mathrm{a}}$, Jin Chuan Wu b*
}

\begin{abstract}
Palm oil empty fruit bunches (EFB) is an abundant and cheap lignocellulose material in South East Asia. Its use as the sole medium for producing lignocellulose-hydrolyzing enzymes would increase its commercial value. A newly isolated Aspergillus niger DSM 26641 was investigated for its capability of producing hemicellulases in EFB hydrolysate obtained by treatment with pressurized hot water $(1-20 \%, w / v)$ at $120-180^{\circ} \mathrm{C}$ in a $1 \mathrm{~L}$ Parr reactor for $10-60$ min. The optimal hydrolysate for the fungal growth and endoxylanase production was obtained when $10 \%$ (w/v) of empty fruit bunch was treated at $120^{\circ} \mathrm{C}$ or $150^{\circ} \mathrm{C}$ for $10 \mathrm{~min}$, giving an endoxylanase activity of $24.5 \mathrm{mU} \mathrm{ml}^{-1}$ on RBB-Xylan and a saccharification activity of $5 \mathrm{U} \mathrm{ml}^{-1}$ on xylan (DNS assay). When the hydrolysates were produced at higher temperatures, longer treatment times or higher biomass contents, only less than $20 \%$ of the above maximal endoxylanase activity was detected, possibly due to the higher carbohydrate concentrations in the medium. Transcriptome analysis showed that 3 endoxylanases (expression levels 59-100\%, the highest level was set as 100\%), $2 \beta$-xylosidases (4\%), 4 side chain-cleaving arabinofuranosidases (1-95\%), 1 acetyl xylan esterase (9\%) and 2 ferulic acid esterases (0.3-9\%) were produced together.

\section{Keywords}

Filamentous Fungi, Submerged culture, Empty fruit bunch, Hydrolysate, Hydrothermal treatment, Endoxylanase, Hemicellulase

a Microbiology and Bioprocess Engineering, Institute of Biochemistry, Leipzig University, 04103 Leipzig, Germany

bIndustrial Biotechnology, A*STAR Institute of Chemical and Engineering Sciences, 1 Pesek Road, Jurong Island, Singapore 627833

Email adresses: christoph@ottenheim.net, carl.xymon.verdejo@gmail.com, wolfgang.zimmermann@uni-leipzig.de,

wu_jinchuan@ices.a-star.edu.sg

*Corresponding author: Dr. Wu jin Chuan, wu_jinchuan@ices.a-star.edu.sg, Tel: +65-67963803; Fax: +65-63166182
\end{abstract}

\section{Preface for this PDF version}

This article is a derivate of the accepted research article published in the Journal of Bioscience and Bioengineering in Vol. 118:6, 696-701 in 2014 through Elsevier. The original article is available under 10.1016/j.jbiosc.2014.05.014. This pdf version is not citable and not meant for commercial use. Every use of this PDF others than for research purpose is not allowed. The storage of this $\mathrm{PDF}$ is only allowed on the first authors private webpage (www.ottenheim.net). A collection in repositories is not approvable. Please link to the article but do not offer downloads of this article. All material in this PDF remain under the original copyright of the article published through Elsevier. For any issues arising from this PDF please contact christoph@ottenheim.net.

\section{Introduction}

Lignocellulose is presently underused as an abundant renewable resource due to the difficulty to separate it into its individual components in a cost-effective way. In Southeast Asia, huge biomass streams are produced as waste materials by the agricultural and forest industries. The biomass waste from palm oil industry in Indonesia 
and Malaysia together accounted for 27 million tons in 2003 [1] and since then, palm oil production has been sharply increased. Lignocellulose is characterized by a high chemical and structural inhomogeneity enhancing its resistance to degradation [2]. A breakdown into its major polymers cellulose (20-50\%), hemicellulose (15-35\%) and lignin (15-35\%) [3, 4] and further into their carbohydrates and phenolic monomers is difficult to achieve in a cost-effective way. Xylan, the major component of hemicellulose in palm oil empty fruit bunch (EFB), is made of a homopolymeric backbone composed of xylopyranose units, which are substituted with side groups of arabinose, glucuronic acid and acetic acid [5]. Xylan forms hydrogen bonds to cellulose and is connected via hydroxycinnamic acids like ferulic acid to lignin [6] making ferulic acid the major cross-linker between hemicellulose and lignin [7]. A chemical or biological pre-treatment of lignocellulose is usually required to access the polysaccharides and their monomers for further utilization [8]. Enzymes can be applied either for hydrolysis of lignocellulose or detoxification of its hydrolysates for further processing [9]. The production of waste and generation of toxic byproducts are drawbacks of chemical pre-treatment methods [10], a sole biological pre-treatment process of lignocellulose would therefore be desirable. A major problem of using enzymes is the high costs, which can be reduced by lowering the enzyme production costs and using more efficient and robust enzymes [11]. Lowering the enzyme production cost can be achieved by on-site enzyme production using lignocellulose hydrolysates as the cell growth and enzyme production medium. Attempts have been made to produce cellulases $[12,13,14]$ and xylanases $[15,16]$ by using lignocellulose hydrolysates as low-cost growth media. Different cellulases are needed for liberating glucose from the cellulose fraction [17]. For complete hydrolysis of hemicellulose, a complex mixture of various backbonedegrading and accessory enzymes are required [18]. The hydrolysis of xylan requires endo-1,4- $\beta$-xylanases (EC $3.2 .1 .8)$ to act on the xylan backbone liberating xylose oligomers, which are further hydrolyzed to xylose by $\beta$ xylosidases (EC 3.2.1.37). The accessory enzymes such as $\alpha$-L-arabinofuranosidase (EC 3.2.1.55), $\alpha$-glucuronidase (EC 3.2.1.139), acetylxylanesterase (EC 3.1.1.72) and ferulic acid esterase (EC 3.1.1.73) are required for degra- dation of various side groups [19].

Recently, we isolated an excellent endo-1,4- $\beta$-xylanaseproducing fungus from the Singaporean natural environment, which was found to grow faster on hydrothermal lignocellulose hydrolysates producing endoxylanases with higher activity than ATCC strains used as controls. Here we report the enzyme production by this new isolate using hydrothermal hydrolysates of EFB as the sole carbon source and the transcriptome analysis of the enzymes. To the best of our knowledge, this is the first report of using EFB hydrolysates as the sole medium for producing hemicelluloses by Aspergillus niger DSM 26641. The use of EFB hydrolysate is believed to be favorable for reducing the enzyme production cost due to its rich availability and low price.

\section{Materials and Methods}

\subsection{EFB processing and hydrothermal treatment}

EFB fibers were obtained from Wawasan Agrolipids Group, Malaysia. After cleaning and air-drying, the fibers were consecutively milled through $8 \mathrm{~mm}, 4 \mathrm{~mm}$, $2 \mathrm{~mm}$ and $1 \mathrm{~mm}$ grinding sieves (Cutting Mill SM100, Retsch, Germany) to obtain the desired particle sizes. The compositions of EFB were determined following the NREL protocols [20, 21, 22]. The hydrothermal experiments were carried out in a $1 \mathrm{~L}$ Parr reactor which was connected to a cooling system for fast temperature reduction after the treatment. The reactor was filled with $300 \mathrm{ml}$ water and desired amounts of EFB. The temperatures were controlled at desired values $\pm 2{ }^{\circ} \mathrm{C}$. After completion of the reaction, the temperature was rapidly reduced to $35^{\circ} \mathrm{C}$ followed by discharging the hydrolysate for subsequent experiments.

\subsection{Experimental design}

Experiments were carried out based on a full factorial design with 4 factors on 3 levels. The reaction temperature (A) and reaction time (B) were chosen as the most important 2 factors because they determine the intensity of the hydrothermal treatment. EFB particle size (C) was selected because it affects the energy consumption during mechanical processing and also affects the hydrolysis efficiency (23). The biomass content in water (D) was chosen because it not only affects the pretreatment 
intensity but also changes the carbohydrate contents in water which severely influences the enzyme production. The reaction temperature was set at conceivable levels of $120^{\circ} \mathrm{C}, 150^{\circ} \mathrm{C}$ and $180^{\circ} \mathrm{C}$, reaction time at $10 \mathrm{~min}, 30$ min and $60 \mathrm{~min}$, EFB particle size at $1 \mathrm{~mm}, 2 \mathrm{~mm}$ and $4 \mathrm{~mm}$ and the EFB biomass content at 1\%,10\% and $20 \%$ (w/v), respectively. The stirring speed was kept constant at $170 \mathrm{rpm}$. All experiments were performed in duplicate.

\subsection{Analytical methods}

EFB hydrolysates were transferred to $50 \mathrm{ml}$ tubes and centrifuged at $3,220 \mathrm{x}$ g for $10 \mathrm{~min}$. After measuring the $\mathrm{pH}$, the absorbance at $400 \mathrm{~nm}$ against water was determined to estimate the amount of humic substances. For estimation of the precipitate, ethanol $(100 \mathrm{ml}$, technical grade) and sodium acetate $(15 \mathrm{ml}, 3 \mathrm{M})$ were added to $50 \mathrm{ml}$ of the centrifuged hydrolysate. After $24 \mathrm{~h}$, the mixture was centrifuged at $3,220 \mathrm{x} g$ for $10 \mathrm{~min}$. The obtained pellet was lyophilized and weighed. For quantification of monomeric sugars and inhibitors, $2 \mathrm{ml}$ of the hydrolysate was centrifuged at $20,800 \mathrm{x}$ g for 30 min. Subsequently, $1 \mathrm{ml}$ of the supernatant was passed through a $0.22 \mu \mathrm{m}$ syringe filter and analyzed by HPLC (LC-10A VP, Shimadzu, Kyoto, Japan) equipped with a Biorad Aminex HPX-87H column (Biorad, California, USA) at $42^{\circ} \mathrm{C}$. The mobile phase was $5 \mathrm{mM} \mathrm{H} 2 \mathrm{SO} 4$ at

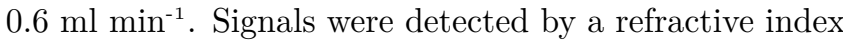
detector (RID-10A, Shimadzu, Kyoto, Japan).

\subsection{Enzyme assay for xylanase activity}

Remazol Brilliant Blue R dyed xylan (RBB-Xylan) was prepared following the procedures of Biely et al. [23]. The centrifuged EFB hydrolysate ( $5 \mathrm{ml}$ ) was transferred into $15 \mathrm{ml}$ tubes and inoculated with a spore suspension of Aspergillus niger DSM 26641 which was isolated from a soil sample in Singapore. The tubes were incubated horizontally at $200 \mathrm{rpm}, 30^{\circ} \mathrm{C}$ for $117 \mathrm{~h}$. Then $1 \%(\mathrm{w} / \mathrm{v})$ RBB-Xylan in $0.25 \mathrm{ml}$ sodium acetate buffer $(100 \mathrm{mM}$, $\mathrm{pH} 5$ ) was added to $0.25 \mathrm{ml}$ culture supernatant and incubated at $50^{\circ} \mathrm{C}$ for $10 \mathrm{~min}$. Ethanol $(1.25 \mathrm{ml}$, technical grade) was added to stop the reaction and precipitate the non-hydrolyzed RBB-Xylan. After centrifugation at $20,800 \mathrm{x}$ g for $10 \mathrm{~min}, 300 \mu \mathrm{l}$ supernatant was transferred to a 96-well plate in duplicate. The absorbance at 590 nm was measured and used to calculate the enzyme activity $\left(\mathrm{mU} \mathrm{ml}^{-1}\right)$. One unit $(\mathrm{U})$ of enzyme is defined as the enzyme activity that liberates $1 \mu \mathrm{mol}$ of Remazol Brilliant Blue from RBB-xylan at $\mathrm{pH} 5$ and $50^{\circ} \mathrm{C}$ within $1 \mathrm{~min}$. All determinations were done in duplicate and the averages were used for statistical analysis.

For comparing the activity of the enzymes obtained on EFB hydrolysate under optimal conditions with those published in literature, the enzyme activity was tested using the 3,5-dinitrosalicylic acid (DNS) assay [24]. Culture supernatant $(30 \mu \mathrm{l})$ was added into $0.3 \mathrm{ml} 1.5 \%$ $(\mathrm{w} / \mathrm{v})$ beechwood xylan in buffers of a desired $\mathrm{pH}$ and the mixture was incubated at desired temperature for 10-20 min. Then $150 \mu$ l DNS reagent was added and the mixture was put in boiling water for $10 \mathrm{~min}$, followed by cooling down in cold water to room temperature and adding $1.5 \mathrm{ml}$ water. Then $300 \mu \mathrm{l}$ of the resulting mixture was taken and transferred to a 96 -well plate. The absorbance at $540 \mathrm{~nm}$ was measured and used to calculate the enzyme activity $\left(\mathrm{U} \mathrm{ml}^{-1}\right)$. The standard curve was prepared using xylose as the reducing sugar. One unit (U) of enzyme is defined as the enzyme activity that liberates $1 \mu \mathrm{mol}$ of reducing sugars within 1 min under the assay conditions. For investigating the capability of Aspergillus niger DSM 26641 for producing enzymes in media richer in nitrogen, inorganic salts and other carbon sources, the EFB hydrolysate was supplemented with $0.05 \%$ yeast extract, mineral salts and EFB fiber for the enzyme production.

\subsection{Data analysis}

Data analysis was conducted using Design Expert Version 8 (Statease Inc., Minneapolis, USA). Prior to analysis, a Box-Cox transformation was used for variance stabilization. The corresponding "Normal-probability plot" was checked for a normal distribution. "Residuals versus Predicted plot" analysis was used to assure a constant variance. Additionally, "Residuals versus Run plot" and "Residuals versus Factor plot" analysis were used to identify possible outliers. Values were analyzed and excluded from the analyses when necessary. Subsequently, factors with significant effects on responses or factor interactions were identified using a "Half-normal Probability plot". Results were reviewed using "One-factor versus Response plots" and "Two Factor versus Response plots". For final 
validation of the model, the "Predicted versus Actual plot" was used and if found sufficient, the corresponding response was included into the final model.

\subsection{Identification of hemicellulases by transcriptome analysis}

Lignocellulose hydrolysate was prepared at the reaction temperature $(\mathrm{A})$ of $150^{\circ} \mathrm{C}$, reaction time $(\mathrm{B})$ of $10 \mathrm{~min}$, particle size (C) of $1 \mathrm{~mm}$ and biomass content (D) of $10 \%$. The hydrolysate was inoculated with a spore suspension of Aspergillus niger DSM 26641 and incubated at $30^{\circ} \mathrm{C}$ and $200 \mathrm{rpm}$ for 4 days. Subsequently, the mycelium was separated from the supernatant and washed with demineralized and sterilized water. The washed mycelium was frozen in liquid nitrogen. After grinding in liquid nitrogen, the mycelial powder was transferred into a $2 \mathrm{ml}$ tube. TrizolTM Reagent (Invitrogen/ Life Technologies, California, USA) was used for deproteination of the sample according to the manufacturer's instruction. For subsequent purification, a Spin Cartridge Kit (Pure Link RNA Mini Kit, Invitrogen, California, USA) was used according to the manufacturer's instruction. For removal of DNA traces, the sample was digested with DNAse I, deactivated with ethylenediaminetetraacetic acid and purified using TrizolTM Reagent. The quality of the isolated RNA sample was checked by agarose gel electrophoresis, UV/VIS spectrophotometry and a Bioanalyzer (Agilent 2100, California, USA). Total RNA was depleted in ribosomal RNA using the Ribominus Eukaryote Kit (Invitrogen/Life Technologies, California, USA). Subsequent preparations were done using the Ion-Total RNA-Seq Kit (Invitrogen/Life Technologies, California, USA). The RNA sample was digested with RNAse III and purified. Subsequently, the size distribution of the fragmented RNA was assessed by the Bioanalyzer. Fragmented RNA of sufficient quality was hybridized, ligated and reverse transcription was performed. cDNA was purified and size-selected for fragments above $150 \mathrm{bp}$ containing a maximum of up to $50 \%$ fragments in the range of 25-160 bp. After amplification and purification, the size distribution of the amplified cDNA was evaluated by the Bioanalyzer. Templated IonSphere particles for sequencing were prepared and used with an Ion Torrent Personal Genome Machine sequencer (Life Technologies, California, USA).

\subsection{Bioinformatic analysis of transcriptome data}

The obtained short reads were mapped on the published reference genome of Aspergillus niger CBS 513.88 [25] using Tophat and Cufflinks [26]. The aligned sequences were investigated by Blast2go [27]. Sequences from the blast results were mapped on the Gene Ontology database [28] to obtain functional information. The mapped sequences were then used for annotation of the corresponding genes followed by assigning an Enzyme Commission Number (EC). The information was used to identify enzymes involved in the hydrolysis of xylan either by EC number, Gene Ontology database results or the assigned enzyme name. The corresponding fragments per kilobase of exon per million fragments mapped (FPKM numbers) were used to indicate a significant expression of the corresponding gene and to estimate an expression level (The highest expression level was set as $100 \%$ ). Transcripts with FPKM numbers smaller or near to one were considered as being not significantly expressed.

\section{Results and Discussion}

\subsection{Effect of operating conditions on chemical com- position of EFB hydrolysates}

EFB contained (dry weight): $36.1 \pm 1 \%$ glucan, $20.7 \pm 0.4 \%$ xylan, $1.8 \pm 0.1 \%$ arabinan, $2.5 \pm 0.1 \%$ acetyl, $20.1 \pm 2.3 \%$ Klason lignin, $1.2 \pm 0.1 \%$ ash and $17.5 \pm 0.8 \%$ others. This result was in line with that reported in literature [29]. The combination of 4 factors at 3 levels in duplicate resulted in totally 162 runs. The valid runs and the main statistical values are shown in Table 1 . The values marked as outliers or equal to zero were excluded from the analyses. The $\mathrm{pH}$ values of the EFB hydrolysates were 4-7, which are in the range suitable for the growth of Aspergillus niger DSM 26641. The main factor affecting the $\mathrm{pH}$ of the hydrolysates was the reaction temperature, whose effect became more significant with increasing reaction time (Fig.1a). Reaction temperature was found to be the second (after biomass content) most significant factor affecting the release of acetic acid (Fig.1b). The concentration of liberated acetic acid reached up to $5 \mathrm{~g} \mathrm{l}^{-1}$. Acetic acid is generally not considered as being inhibitory to microbial growth when its concentration is below $6 \mathrm{~g} \mathrm{l}^{-1}[30]$, but the presence of acetic acid might 
A

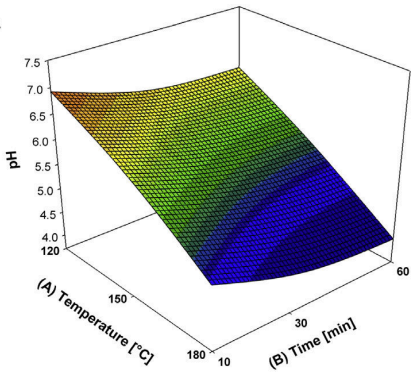

C

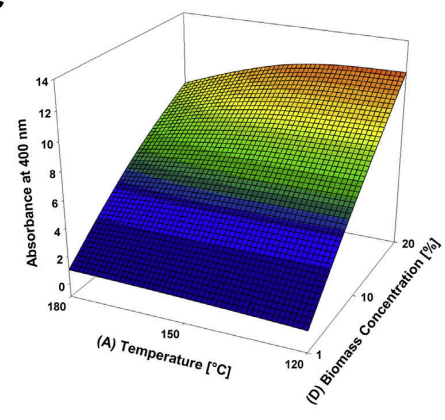

$\mathbf{E}$

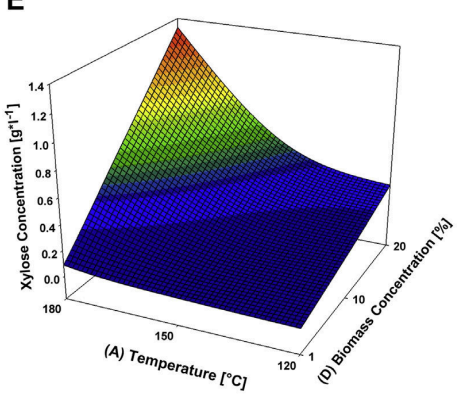



D

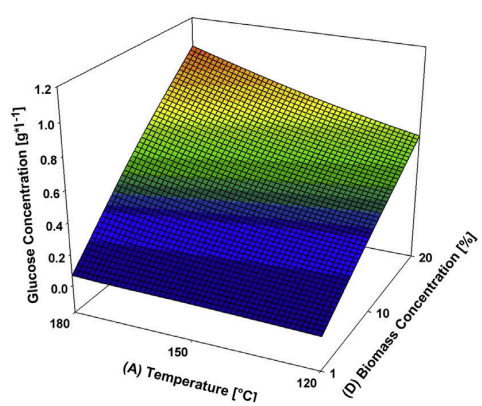

$\mathbf{F}$

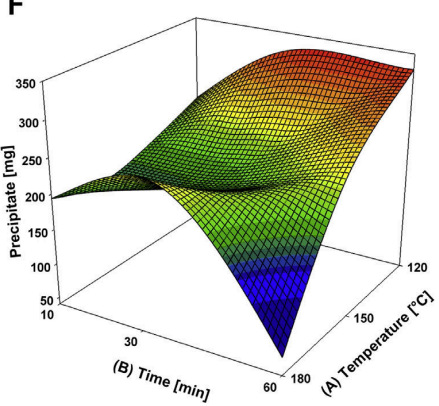

Fig. 1: Significant relations between responses and factors for EFB hydrothermal treatment (A) Temperature and time with $\mathrm{pH}$; (B) temperature and biomass concentration with acetic acid content; (C) temperature and biomass concentration with absorbance of hydrolysate; (D) temperature and biomass concentration with glucose concentration; (E) temperature and biomass concentration with xylose concentration; $(\mathrm{F})$ time and temperature with precipitate amount

\begin{tabular}{|c|c|c|c|c|c|c|}
\hline Response & Unit & Valid Runs & Minimum & Maximum & Mean & Standard Deviation \\
\hline pH & - & 157 & 4.02 & 7.02 & 5.53 & 0.87 \\
\hline Absorbance at $400 \mathrm{~nm}$ & mg & 159 & 0.46 & 15.2 & 5.61 & 4.22 \\
\hline Precipitate & $\mathrm{g} \mathrm{l}^{-1}$ & 155 & 0.84 & 845.4 & 216.6 & 195.0 \\
\hline Glucose & $\mathrm{g} \mathrm{l}^{-1}$ & 155 & 0.03 & 1.21 & 0.44 & 0.33 \\
\hline Xylose & $\mathrm{g} \mathrm{l}^{-1}$ & 157 & 0.01 & 2.71 & 0.37 & 0.48 \\
\hline Arabinose & $\mathrm{g} \mathrm{l}^{-1}$ & 152 & 0 & 0.98 & 0.23 & 0.23 \\
\hline Acetic acid & $\mathrm{g} \mathrm{l}^{-1}$ & 159 & 0 & 4.92 & 1.05 & 1.07 \\
\hline 5-Hydroxymethylfurfural & $\mathrm{g} \mathrm{l}^{-1}$ & 104 & 0 & 0.12 & 0.02 & 0.02 \\
\hline Furfural & $\mathrm{g} \mathrm{l}^{-1}$ & 46 & 0 & 1.02 & 0.21 & 0.3 \\
\hline Xylanase activity & $\mathrm{mU} \mathrm{ml}^{-1}$ & 66 & 0 & 24.5 & 5.8 & 6.25 \\
\hline
\end{tabular}




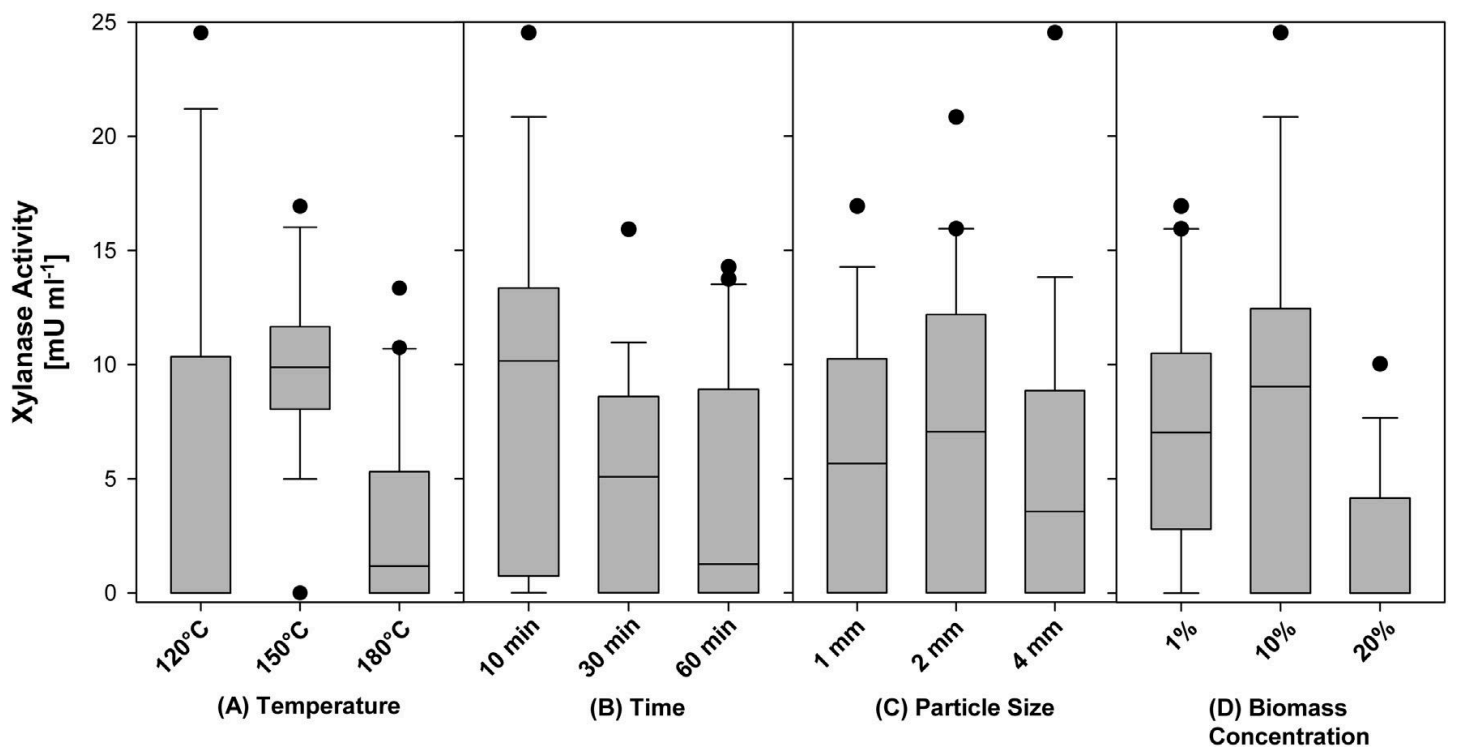

Fig. 2: Effect of different factors for EFB hydrothermal treatment on xylanase activity (A) Temperature, (B) time, (C) particle size, and (D) biomass concentration.

$($ Box limiter $=25,75$ percentile; centered line $=$ median; dots $=$ outliers; whiskers $=10,90$ percentile $)$.

\begin{tabular}{|c|c|c|c|}
\hline \multicolumn{4}{|c|}{ obtained by hydrothermal treatment of EFB } \\
\hline Identified Genes & Domain(s) & FPKM* & Nearest Match \\
\hline \multicolumn{4}{|l|}{ Xylan-hydrolyzing Enzymes } \\
\hline \multicolumn{4}{|c|}{ Endo-1,4- $\beta$-xylanases (EC 3.2.1.8) } \\
\hline Endo- $1,4-\beta$-xylanases Xyn11B & GH11 & 369.3 & HQ724285.1 \\
\hline Endo-1,4- $\beta$-xylanases B & GH11 & 248 & XM_001388485.2 \\
\hline Endo- $1,4-\beta$-xylanases F1 & GH10 & 216.9 & XM_001389959.2 \\
\hline \multicolumn{4}{|l|}{$\beta$-Xylosidases (EC 3.2.1.37) } \\
\hline Exo-1,4- $\beta$-xylosidase $x \ln D$ & GH3 & 15.6 & XM_001389379.2 \\
\hline Xylosidase:Arabinofuranosidase & GH43-GH62-GH32-GH68 & 14.9 & XM_001392272.2 \\
\hline \multicolumn{4}{|l|}{ Accessory Enzymes } \\
\hline$\alpha$-L-arabinofuranosidase axhA & GH62 & 352.4 & XM_001389961.2 \\
\hline$\alpha$-N-arabinofuranosidase B & GH54, CBM42 & 64.2 & XM_001396732.2 \\
\hline$\alpha$-N-arabinofuranosidase $\mathrm{C}$ & GH51 & 10.2 & XM_001392253.1 \\
\hline$\alpha$-N-arabinofuranosidase $\mathrm{A}$ & GH51 & 3.9 & XM_001388445.1 \\
\hline \multicolumn{4}{|c|}{ Acetylxylanesterases (EC 3.1.1.72) } \\
\hline Acetylxylan esterase A & Esterase_phb & 34.6 & XM_001395535.2 \\
\hline \multicolumn{4}{|c|}{ Ferulic Acid esterases (EC 3.1.1.73) } \\
\hline Feruloyl esterase A & Lipase_3 & 32.6 & XM_001393300.2 \\
\hline Feruloyl esterase B-1 & Tannase & 1.2 & XM_001396048.2 \\
\hline
\end{tabular}


enhance the release of monomeric sugars from lignocellulose biomass [31]. Lignin and its degradation products are considered as inhibitors for microbial growth [32]. Therefore, conditions leading to high amounts of humic substances in the hydrolysate should be avoided. Due to the difficulty in accurately measuring the lignin degradation products, the spectrophotometric assay at 400 $\mathrm{nm}$ was used to detect the formation of humic acids, which is related to the degradation of lignin [33]. With increasing the biomass content, more humic substances were formed. At higher temperatures and biomass contents, partial degradation of humic substances took place leading to a slightly lower absorbance (Fig.1c). Furfural and 5-hydroxymethylfurfural (HMF) are decomposition products of monomeric sugars and have been recognized as strong inhibitors to cell growth. Furfural reached $1 \mathrm{~g} \mathrm{l}^{-1}$ maximally in EFB hydrolysates while HMF was peaked at $0.1 \mathrm{~g} \mathrm{l}^{-1}$. Reaction temperature, time and biomass content are the 3 major factors affecting the formation of growth inhibitors including furfural and HMF. Considerable amount of furfural and HMF were detected at $180^{\circ} \mathrm{C}$ with extended reaction time and increased biomass content. The concentrations of monomeric sugars were $<0.5 \mathrm{~g} \mathrm{l}^{-1}$ in most cases but reached $2 \mathrm{~g} \mathrm{l}^{-1}$ in rare cases. Monomeric sugars at high concentrations act as catabolite repressors for the production of xylanases [34]. Therefore, maintaining low concentrations of monomeric sugars should be targeted to favor the enzyme production. The release of glucose and xylose was mainly influenced by the biomass content followed by the reaction temperature (Figs.1d, 1e), while the release of arabinose was mainly affected by the reaction temperature and the interaction between reaction temperature and biomass content. The release of precipitate from EFB was mainly influenced by the biomass content. As increasing reaction time and temperature led to the degradation of oligomers and polymers to monomers, higher reaction temperature and longer reaction time should be avoided to reduce the degradation of oligomers and polymers (Fig.1f).

\subsection{Production of xylanases by Aspergillus niger DSM 26641}

The optimal conditions for producing xylanases by $A s$ pergillus niger DSM 26641 grown on EFB hydrolysate were obtained by a half-normal plot and comparative boxplot analysis (Fig.2) of the experimental data. The reaction temperature for EFB hydrothermal treatment was identified as being the most important factor that affected the enzyme production. In the EFB hydrolysate prepared at $150^{\circ} \mathrm{C}$, the enzyme activity produced by Aspergillus niger was higher compared to that in the EFB hydrolysates prepared at $120^{\circ} \mathrm{C}$ and $180^{\circ} \mathrm{C}$ (Fig.2a). At biomass contents of $1 \%$ and $10 \%$, the hydrolysates yielded the highest enzyme activities produced by $A s$ pergillus niger. When the biomass content was increased to $20 \%$, the enzyme activity was obviously decreased (Fig.2d). The hydrolysates prepared at higher temperatures and longer reaction times resulted in lower enzyme activities. Therefore, lower reaction temperatures and shorter reaction times are preferable for obtaining high xylanase activity (Fig.2b).

\begin{tabular}{|c|c|c|c|c|}
\hline Filamentous fungus & Enzyme production substrate & Assay Conditions & $\begin{array}{l}\text { Xylanase Activity } \\
\qquad\left(\mathrm{U} \mathrm{ml}^{-1}\right.\end{array}$ & Reference \\
\hline A. niger SBS28 & $0.1 \%$ birch wood xylan, mineral salts & $\mathrm{pH} 5.3,50^{\circ} \mathrm{C}$ & 39 & {$[35]$} \\
\hline A. niger D41 & $\begin{array}{c}1 \% \text { birch wood xylan, mineral salts, } \\
\text { trace elements }\end{array}$ & $\mathrm{pH} 5.3,50^{\circ} \mathrm{C}$ & $36.35^{*}$ & {$[36]$} \\
\hline A. niger DSM 26641 & $\begin{array}{c}\text { Lignocellulose hydrolysate, } 3 \% \text { EFB fiber, } \\
0.05 \% \text { yeast extract, mineral salts }\end{array}$ & $\begin{array}{l}\mathrm{pH} 5,50^{\circ} \mathrm{C} \\
\mathrm{pH} 5,50^{\circ} \mathrm{C}\end{array}$ & 33 & this study \\
\hline A. niger C28B25 & $\begin{array}{c}1 \% \text { birch wood xylan, mineral salts, } \\
\text { trace elements }\end{array}$ & $\mathrm{pH} 5.3,50^{\circ} \mathrm{C}$ & $18.26^{*}$ & {$[37]$} \\
\hline Aspergillus spec. PK7 & $1 \%$ oat spelt xylan, yeast extract & $\mathrm{pH} 4.8,50^{\circ} \mathrm{C}$ & 10.6 & [38] \\
\hline A. niger DSM 26641 & Lignocellulose hydrolysate, $3 \%$ EFB fiber & $\mathrm{pH} 5,50^{\circ} \mathrm{C}$ & 10 & this study \\
\hline A. niger DSM 26641 & $\begin{array}{l}\text { Lignocellulose hydrolysate, } \\
\text { additional nitrogen sources }\end{array}$ & $\mathrm{pH} 5,50^{\circ} \mathrm{C}$ & 6 & this study \\
\hline A. niger DSM 26641 & Lignocellulose hydrolysate & $\mathrm{pH} 5,50^{\circ} \mathrm{C}$ & 5 & this study \\
\hline
\end{tabular}


The production of xylanases was found to be almost independent of the EFB particle size (Fig.2c). This might indicate that the particle size did not affect the formation of solubilized substances to a significant level thus not influence the growth of the fugal cells in the liquid phase. The hydrolysates yielding high xylanase activities had a $\mathrm{pH}$ of 5-7, while the hydrolysates with a $\mathrm{pH}$ of 4-5 gave lower enzyme activities. High xylanase activities were also observed with EFB hydrolysates containing low amounts of humic substances and monomeric sugars (0.5-1.0 $\left.\mathrm{g} \mathrm{l}^{-1}\right)$ including glucose, xylose and arabinose. At a monomer sugar concentration as high as $4.4 \mathrm{~g} \mathrm{l}^{-1}$ in the hydrolysate, the xylanase activity was obviously decreased. Low concentrations of furfural, HMF and acetic acid in the hydrolysates were favorable for yielding high xylanase activity. There is no report on using hydrothermal hydrolysates of lignocellulose to produce xylanases by filamentous fungi in submerged cultures. Xylan, a lignocellulose derivative, was repeatedly used together with yeast extract, mineral salts and trace elements to produce xylanases (Table 3 ), giving a xylan saccharification activity ranging from $10-39 \mathrm{U} \mathrm{ml}^{-1}$ at $\mathrm{pH} 5$ and $50^{\circ} \mathrm{C}$. In our case using hydrothermal hydrolysates of lignocellulose as the sole medium, the maximal xylan saccharification activity was $5 \mathrm{U} \mathrm{ml}^{-1}$ under the same conditions. To further improve the xylanases activity, we supplemented either yeast extract or EFB fiber or both at $40 \mathrm{~h}$, resulting in a xylanase activity of $33 \mathrm{U} \mathrm{ml}^{-1}$ when both were added and $10 \mathrm{U} \mathrm{ml}^{-1}$ when only EFB fiber was added. We also tried to add yeast extract alone to the system achieving a xylanase activity of only $6 \mathrm{U} \mathrm{ml}^{-1}$. Therefore, the co-addition of small amount of nitrogen source and original EFB fiber is an effective to increase xylanase production than adding either of them alone. However, the supplement of extra nutrients may increase the enzyme production cost. It is thus necessary to optimize the enzyme production medium and process to get low cost enzymes for industrial applications.

\subsection{Transcriptome analysis of xylanases produced by Aspergillus niger}

The expression of all hemicellulases by Aspergillus niger DSM 26641 grown in EFB hydrolysate prepared under the optimal conditions for xylanase production was analyzed by ion torrent sequencing (Table 2). It is seen that not only the xylanases (endoxylanases and xylosidases) which are responsible for the hydrolysis of xylan backbone, but the side-chain cleaving enzymes including arabinofuranosidases, acetyl xylan esterase and ferulic acid esterase were also expressed. Three different endoxylanases were identified to belong to the glycoside hydrolase families 10 and 11. Endoxylanases, the key xylanases responsible for cleaving xylan backbone to oligomers of different sizes, showed the highest expression levels (59-100\%, the highest level was set as 100\%) among all enzymes. Two different xylosidases (4\%), which are in charge of degrading the produced oligomers to xylose, were identified. One is with bi-functional feature (xylosidase and arabinofuranosidase activities), which is beneficial as it can help cleave the arabinan side chain from oligomers. In addition, four arabinofuranosidases (1-95\%) were found, one of them belongs to the glycoside hydrolase family 62 and was expressed at a level similar to endoxylanases. This might reflect the difficulty in degrading the arabinan in EFB as its content $(1.8 \pm 0.1 \%)$ is much lower than that $(20.7 \pm 0.4 \%)$ of xylan. Cleavage of the arabinan side chain would promote the degradation of the xylan backbone [39]. One acetyl xylan esterase (9\%) and two feruloyl esterases (0.3-9\%) were expressed at lower but not negligible levels, indicating the importance of removal of acetyl and ferulic acid residues for complete hydrolysis of EFB to monomer sugars.

Summarized, the hydrothermal treatment of EFB was investigated to get the hydrolysates for use as the sole medium to produce xylanases by Aspergillus niger DSM 26641. The optimal conditions for the hydrothermal treatment of EFB were obtained: EFB content $10 \%$, temperature $120^{\circ} \mathrm{C}$ or $150^{\circ} \mathrm{C}$, reaction time $10 \mathrm{~min}$.

The EFB hydrolysate thus prepared yielded not only large amounts of xylanases (endoxylanase and $\beta$-xylosidaes) that are responsible for cleaving the xylan backbone but also considerable amounts of the side-chain hydrolyzing enzymes (arabinofuranosidases, acetyl xylan esterase, feruloyl esterases). Higher treatment temperatures and longer reaction times for EFB treatment should be avoided to reduce the formation of inhibitory byproducts in the hydrolysates and maintain a suitable $\mathrm{pH}$ for the fungal growth to favor the enzyme production. 


\section{Acknowledgments}

This work was supported by the Science and Engineering Research Council (SERC) of the Agency for Science, Technology and Research (A*STAR) under the ValueAdded Chemicals from Lignocellulose (VACL) Program (SERC grant no. 0921590133) and Biomass to Chemicals Program (SERC grant no 1124004027) through the A*STAR Research Attachment Program (ARAP) Scholarship.

\section{References}

[1] R. M. Carlos and D. Ba Khang. Characterization of biomass energy projects in southeast asia. Biomass Bioenergy, 32:525-532, 2008.

[2] J. S. Van Dyk and B. I. Pletschke. A review of lignocellulose bioconversion using enzymatic hydrolysis and synergistic cooperation between enzymes, factors affecting enzymes, conversion and synergy. Biotechnol. Adv., 30:1458-1480, 2012.

[3] J. Ni and G. Tokuda. Lignocellulose-degrading enzymes from termites and their symbiotic microbiota. Biotechnol. Adv., 31:838-850, 2013.

[4] P. Azadi, O. R. Inderwildi, R. Farnood, and D. A. King. Liquid fuels, hydrogen and chemicals from lignin: a critical review. Renew. Sust. Energ. Rev., 21:506-523, 2013.

[5] R. Deutschmann and R. F. Dekker. From plant biomass to bio-based chemicals: latest developments in xylan research. Biotechnol. Adv., 30:1627-1640, 2012.

[6] T. Ishii. Structure and functions of feruloylated polysaccharides. Plant Sci., 127:111-127, 1997.

[7] A. Chesson. Lignin-polysaccharide complexes of the plant cell wall and their effect on microbial degradation in the rumen. Anim. Feed Sci. Technol., 21:219-228, 1988.

[8] G. Jaeger and J. Buechs. Biocatalytic conversion of lignocellulose to platform chemicals. Biotechnol. J., 7:1122-1136, 2012.

[9] E. Palmqvist and B. Hahn-Hägerdal. Fermentation of lignocellulosic hydrolysates. i: inhibition and detoxification. Bioresour. Technol., 74:17-24, 2000.
[10] M. Tomás-Pejró, P. Alvira, M. Ballesteros, and M. Negro. Pretreatment technologies for lignocellulose-to-bioethanol conversion. in: Pandey, A., Larroche, C., Ricke, S. C., Dussap, C.-G., and Gnansounoi, E. (Eds.), Biofuels: alternative feedstocks and conversion processes. Academic Press, Waltham, pages 149-176, 2011.

[11] L. Viikari, J. Vehmaanpera, and A. Koivula. Lignocellulosic ethanol: from science to industry. Biomass Bioenergy, 46:13-24, 2012.

[12] K. Kovacs, G. Szakacs, and G. Zacchi. Comparative enzymatic hydrolysis of pretreated spruce by supernatants, whole fermentation broths and washed mycelia of Trichoderma reesei and Trichoderma atroviride. Bioresour. Technol., 100:1350-1357, 2009.

[13] M. S. Umikalsom, A. B. Ariff, H. S. Zulkifli, C. C. Tong, M. A. Hassan, and M. I. A. Karim. The treatment of oil palm empty fruit bunch fibre for subsequent use as substrate for cellulase production by Chaetomium globosum kunze. Bioresour. Technol., 62:1-9, 1997.

[14] E. Palmqvist, B. Hahn-Hägerdal, Z. Szengyel, G. Zacchi, , and K. Rèczey. Simultaneous detoxification and enzyme production of hemicellulose hydrolysates obtained after steam pretreatment. Enzyme. Microb. Technol., 20:286-293, 1997.

[15] T. Juhász, Z. Szengyel, K. Réczey, M. Siika-Aho, and L. Viikari. Characterization of cellulases and hemicellulases produced by Trichoderma reesei on various carbon sources. Process Biochem., 40:35193525, 2005.

[16] L. A. Oliveira, A. L. Porto, and E. B. Tambourgi. Production of xylanase and protease by Penicillium janthinellum crc $87 \mathrm{~m}-115$ from different agricultural wastes. Bioresour. Technol., 97:862-867, 2006.

[17] T. Hasunuma, F. Okazaki, N. Okai, K. Y. Hara, J. Ishii, and A. Kondo. A review of enzymes and microbes for lignocellulosic biorefinery and the possibility of their application to consolidated bioprocessing technology. Bioresour. Technol., 135:513-522, 2013.

[18] M. L. Polizeli, A. C. Rizzatti, R. Monti, H. F. Terenzi, J. A. Jorge, and D. S. Amorim. Xylanases 
from fungi: properties and industrial applications. Appl. Microbiol. Biotechnol., 67:577-591, 2005.

[19] V. Juturu and J. C. Wu. Microbial xylanases: engineering, production and industrial applications. Biotechnol. Adv., 30:1219-1227, 2012.

[20] A. Sluiter, D. Crocker, B. Hames, R. Ruiz, C. Scarlata, J. Sluiter, and D. Templeton. Determination of structural carbohydrates and lignin in biomass. technical report no. nrel/tp-510-42618. National Renewable Energy Laboratory, Golden, 2008.

[21] A. Sluiter, B. Hames, R. Ruiz, C. Scarlata, J. Sluiter, and D. Templeton. Determination of ash in biomass. technical report no. nrel/tp-510-42622. National Renewable Energy Laboratory, Golden, 2005.

[22] A. Sluiter, B. Hames, D. Hyman, C. Payne, R. Ruiz, C. Scarlata, J. Sluiter, D. Templeton, and J. Wolfe. Determination of total solids in biomass and total dissolved solids in liquid process samples. technical report no. nrel/tp-510-42621. National Renewable Energy Laboratory, Golden, 2008.

[23] P. Biely, D. Mislovicová, and R. Toman. Remazol brilliant blue-xylan: a soluble chromogenic substrate for xylanases. Methods Enzymol., 160:536-541, 1988.

[24] G. L. Miller. Use of dinitrosalicylic acid reagent for determination of reducing sugar. Anal. Chem., 31:426-428, 1959.

[25] H. J. Pel, J. H. de Winde, D. B. Archer, P. S. Dyer, G. Hofmann, P. J. Schaap, G. Turner, R. P. de Vries, R. Albang, K. Albermann, and other 59 authors. Genome sequencing and analysis of the versatile cell factory Aspergillus niger cbs 513.88. Nat. Biotechnol., 25:221-231, 2007.

[26] C. Trapnell, A. Roberts, L. Goff, G. Pertea, D. Kim, D. R. Kelley, H. Pimentel, S. L. Salzberg, J. L. Rinn, and L. Pachter. Differential gene and transcript expression analysis of rna-seq experiments with tophat and cufflinks. Nat. Protoc., 7:562-578, 2012.

[27] A. Conesa, S. Goetz, J. M. Garcia-Gomez, J. Terol, M. Talón, and M. Robles. Blast2go: a universal tool for annotation, visualization and analysis in functional genomics research. Bioinformatics, 21:36743676, 2005.
[28] The Gene Ontology Consortium. Gene ontology: tool for the unification of biology. Nat. Genet., 25:25-29, 2009.

[29] D. Zhang, Y. L. Ong, Z. Li, and J. C. Wu. Optimization of dilute acid-catalyzed hydrolysis of oil palm empty fruit bunch for high yield production of xylose. Chem. Eng. J., 181-182:636-642, 2012.

[30] i. Palmqvist, e. and hahn-hägerdal, b.: Fermentation of lignocellulosic hydrolysates. ii: inhibitors and mechanisms of inhibition. Bioresour. Technol., 74:2533, 2000.

[31] C. K. Nitsos, K. A. Matis, and K. S. Triantafyllidis. Optimization of hydrothermal pretreatment of lignocellulosic biomass in the bioethanol production process. ChemSusChem, 6:110-122, 2013.

[32] I. Boukari, M. O'Donohue, C. Rémond, and B. Chabbert. Probing a family gh11 endo-beta-1,4-xylanase inhibition mechanism by phenolic compounds, role of functional phenolic groups. J. Mol. Catal. B Enzym., 72:130-138, 2011.

[33] C. Mettel, Y. Kim, P. M. Shrestha, and W. Liesack. Extraction of mrna from soil. Appl. Environ. Microbiol., 76:5995-6000, 2010.

[34] F. Piñaga, M. T. Fernández-Espinar, S. Vallés, and D. Ramón. Xylanase production in Aspergillus nidulans: induction and carbon catabolite repression. FEMS Microbiol. Lett., 115:319-323, 1994.

[35] S. G. Nair and R. Sindhu. Fungal xylanase production under solid state and submerged fermentation conditions. Afr. J. Microbiol. Res., 2:82-86, 2008.

[36] R. Sudan and B. K. Bajaj. Production and biochemical characterization of xylanase from an alkalitolerant novel species Aspergillus niveus rs2. World J. Microbiol. Biotechnol., 23:491-500, 2007.

[37] O. Loera and J.i Córdova. Improvement of xylanase production by a parasexual cross between Aspergillus niger strains. Braz. Arch. Biol. Technol., 46:177-181, 2003.

[38] P. Khanna, S. S. Sundari, and N. J. Kumar. Production, isolation and partial purification of xylanases from an Aspergillus sp. World J. Microbiol. Biotechnol., 11:242-243, 1995. 
[39] R. de Vries, H. Kester, C. Poulsen, J. Benen, and J. Visser. Synergy between enzymes from aspergillus involved in the degradation of plant cell wall polysaccharides. Carbohydr. Res., 327:401-410, 2000. 